Maria Molina

Institute of Linguistics, Russian Academy of Sciences, Moscow; maria.molina@iling.ran.ru

\title{
Degrees of comparison in Hittite and Luwian ${ }^{1}$
}

In this paper I analyze degrees of gradation in Hittite, looking at equative, similative, comparative, superlative, elative and excessive semantics in Hittite myths, prayers, letters and instructions, in comparison with Luwian data. The results may work towards a better understanding of degree formation in Indo-European languages, with implications for possible reconstructions of Proto-Anatolian and Proto-Indo-European. Corpus approach and contextual analysis applied to Hittite material help to extract contexts that are not explicit and might be described as pragmatic means of expressing gradation semantics. The paper aims at shedding light on the early processes in Indo-European comparative morphology, as attested in Anatolian languages.

Keywords: Hittite language; comparative syntax; historical semantics; corpus approach; degrees of gradation.

\section{Introduction}

When speaking of gradation degrees, we typically mean degrees of comparison in adjectives and adverbs (cf. Luján 2019: 306), which is not completely without reason: gradation can be construed as a quantifiable feature on a scale compared to a certain standard ('as big as an elephant'). Consequently, this implies attributive semantics, most frequently expressed in the world's languages by adjectives, adverbs and adjectival verbs. Exploring gradation as a universal semantic category in a language, we have to take into account the other means of its expression as well, including syntactic and pragmatic. These might also include morphological means (cases of comparison), parallel sentences with comparison semantics, elements of information structure (foci). Not all of them can easily be spotted in a dead language with a closed corpus, which led to certain gaps in grammar of Anatolian languages. Our paper aims at filling this gap, with a distant purpose to acquire necessary details for a wider comparison both within the Anatolian family and, beyond it, with Narrow Indo-European languages, and for more informed attempts at reconstruction of Proto-Indo-European comparative morphosyntax.

Hittite is an ancient Indo-European language attested on numerous clay tablets 18-12 cc. BC; it belongs to the Anatolian family, along with Palaic, Lydian, Luwian, Lycian, Carian, Sidetic, and Pisidian. It should be noted that of all Anatolian languages Hittite has the biggest uncovered corpus of documents, preserved in royal archives of Hattusa and other cities of the Hittite Empire. Another language of this family, Luwian, remained in widespread use throughout the Hittite Empire and even at the very heart of it, the capital city of Hattusa (see Yakubovich 2010 on Luwian sociolinguistics), which resulted in significant areal contacts between the two languages. Both Luwian and Hittite are attested in cuneiform, while Luwian is also attested in hi-

${ }^{1}$ Work on the paper was supported by the financial aid from the project RSF \#18-18-00503 “The most ancient poetic systems of the world: from Sumerian to Ancient Greek". I express my gratitude to Ilya Yakubovich, Paul Widmer, and Katsiaryna Ackermann for discussing different aspects of gradation semantics in Anatolian and Indo-European languages. All the mistakes are naturally mine.

Journal of Language Relationship • Вопросы языкового родства • 17/4 (2019) • Pp. 297-309 • ( The authors, 2019 
eroglyphic inscriptions (Yakubovich 2010, 2019). Cuneiform was adopted by the Hittites from Old Akkadian scribing schools, Akkadian being lingua franca in the Ancient Near East of II millennium BC, Old Hittite documents of 18 c. BC mostly written in Akkadian. Cuneiform writing, therefore, contains a lot of Akkadian and Sumerian logograms, sometimes accompanied by phonetic complements to help readers better understand the Hittite cases and verb endings. The phonetic complements allow us to know that the texts were indeed read in Hittite, and not in Akkadian (except in many cases when Hittite scribes wrote in proper Akkadian; see also Kudrinski, Yakubovich 2016)2.

Certain obstacles to analysing meaning in Hittite and Luwian, extinct languages with no access to testing semantics in an experiment (the usual practice for living languages), should be discussed here. The need for a semantic test is commonly justified by the presence of homonyms and homographs in any language, and by the ability of the same words to function as different parts of speech, which is the case with Hittite: for example, conjunctions/particles mahhan and mān are attested as both adjectives and adverbs.

In turn, conjunctions might well be comparative particles or relative pronouns; fragmented structure of the Hittite texts often makes it difficult to understand the words' current function. But in the case of dead languages we can only apply contextual analysis, supported by the philological method, which noticeably lessens effects of automatic natural language processing (NLP). Since there are almost no completely preserved tablets and texts in Hittite, we have to include fragmented sentences to illustrate degrees of comparison if semantics is clear, even when the whole context is badly preserved.

\section{The corpus and the method applied}

There are two main sources for the Hittite corpus exploited for the purpose of the current paper. The first one is the online corpus of Hittite letters and instructions (http://hittitecorpus.ru) digitalised and annotated by the author, built on material published in "Letters from the Hittite Kingdom" (Hoffner 2009) and "Hittite Royal Instructions" (Miller 2013). The second consists of Hittite prayers published online by Rieken et al., which have also been used as material for my research, with a limited addition of Hittite myths from the same source. There is one solid reason to look for degrees of comparison in myths, hymns, prayers and certain kinds of letters and instructions more than in any other types of texts; choice of material has been influenced by the common topics of those texts, where someone or something is often compared to other things or people ("thou art the best of all deities", "this message is just what one would expect from my brother", "this place is very important", "he was as (fast) a spear, as (ferocious) as a lion", etc.). All in all, an amount of up to 9000 clauses has been involved in the current research (4984 for letters and instructions, around 3000 clauses in the online prayer corpus, and around 1000 clauses in myths). Occasionally, there are examples from classical Hittite grammar (Hoffner, Melchert 2008) and the Chicago Hittite Dictionary (CHD), consulted when my limited corpus has not yielded specific data on the degrees of comparison in Hittite. The list of all the sources and their editions is given sub References. Luwian material includes the

2 The established practice of cuneiform transliteration is to use small letters for Hittite, capital letters for Sumerian, and capital italic for Akkadian. The same applies to the Hittite and Luwian contexts in the paper below. As far as fragmented pieces are concerned, square brackets mark broken parts and the text restored philologically; round brackets mark parts restored from copies of the text. Superscript marks determinatives (word classes which were probably not pronounced in reading), subscribed digits mark homophonous logograms. 
well-understood bilingual inscription KARATEPE (following Yakubovich 2013), where Phoenician reading can be compared to help making the meaning clear, a building inscription of Katuwa, ruler of Carchemish, and some other texts from the Annotated Corpus of Luwian Texts (ACLT).

The methodological basis for the paper can be described as follows. Gradation, following common practice, is defined as an act by which an entity is explicitly assigned a position relative to some other contextually relevant value on a gradable predicative scale. E.g., in (1) Peter is placed on the scale of a body size, where 'rather' assigns a graded value to the quality:

(1) Peter was rather tall.

Based on Small's classification of equal and unequal (Small 1929: 12-13), Hahnemann suggested the following classification (Hahnemann 1999:2, which is quite consistent with any other attempt at theoretical descriptions of gradation and comparison that I am aware of, including Haspelmath \& Buchholz 1998, Haspelmath 2017, Gorshenin 2012, Dixon 2012). Two entities $x$ and $y$ are involved in comparison. There might be one or two predicates that attribute properties $P$ and $Q$ to $x$ and $y$. Their relative positions on the scale can be expressed as $P(x)$ and $Q(y)$. The entities may refer to different $(x \neq y)$ or the same $(x=y)$ referents. $X$ is a comparee (CMPREE), $y$ is a standard of comparison (STAND). The properties are called parameters (PAR). The standard and the parameter have their markers (STM, PM) which may be a separate word (a function word, a particle, an adverb) or a case (a morpheme or a preposition phrase). Parameters may be expressed as verbs/adjectives. A semantic classification has also been developed (following literature mentioned above), see Table 1.

Table 1. Types of gradation

\begin{tabular}{l|l}
\hline equative & $\mathrm{X}$ is exactly the same as $\mathrm{Y}$ \\
\hline similative & $\mathrm{X}$ is like $\mathrm{Y}$ \\
\hline comparative of superiority/majority & $\mathrm{X}$ is more than $\mathrm{Y}$ \\
\hline comparative of inferiority/minority & $\mathrm{X}$ is less than $\mathrm{Y}$ \\
\hline superlative of superiority/majority & $\mathrm{X}$ is the best of $\mathrm{Y}$ \\
\hline superlative of inferiority/minority & $\mathrm{X}$ is the worst of $\mathrm{Y}$ \\
\hline elative & $\mathrm{X}$ is very $\mathrm{Y}$ \\
\hline excessive & $\mathrm{X}$ is too much $\mathrm{Y}$ \\
\hline
\end{tabular}

All in all, there are 11 types of possible combinations for described parameters, in addition to sentences with two predicates ("The room is wider than it is longer"; "As my mother gave me birth, you, Sun God, pour life back in me"). Not all of them, however, can be applied to Anatolian languages. Our first goal in this paper was to build a classification of those types that are attested in Hittite and Luwian, and to compare these languages, with the assistance of corpus approach.

\section{Hittite and Luwian evidence}

It will be shown below that Hittite possesses a rather limited range of forms and structures denoting degrees of comparison when compared to Narrow Indo-European languages; for example, it almost never uses adpositions to address comparative semantics. Postpositions in Hittite corpus are introduced only to deliver similative and superlative semantics. Citing Ilya 
Yakubovich, "a well-established feature of the Hittite language, which separates it from the better-known ancient Indo-European languages, such as Latin, Greek, or Vedic, is the lack of morphological expression for the comparative and superlative degrees of adjectives (Hoffner, Melchert 2008: 273-276)”.

For the most part, Hittite uses syntactic and pragmatic means to express comparatives and superlatives - indeed, there are no morphological tools for comparison that could be compared to Greek - $\omega \omega v,-\iota \sigma \tau o \varsigma,-\tau \varepsilon \varrho o \varsigma,-\tau \alpha \tau o \varsigma$, Latin -ior, -issimus, or English -er, -(e)st. Assuming that formation of degrees of comparison could start independently in Anatolian languages, it would be interesting to look at the material of Anatolian languages in light of morphosyntactic approach to gradation. Unfortunately, the corpus approach here is mainly applicable to Hittite material, since the Hittite corpus is so much better elaborated for these purposes. Some Luwian examples, however, managed to be extracted from ACLT and from Yakubovich 2013. The latter work is particularly interesting in that it shows (p. 157) that, by contrast with Hittite, Luwian supplies us with at least one morphologically expressed superlative.

The Luwian similative, using a postposition, is found in cuneiform Luwian, the Ritual of Puriyanni:

(2) CTH 758.1.B, KUB 35.54 rev. iii 24-26 (Ritual of Puriyanni against pollution of the house)

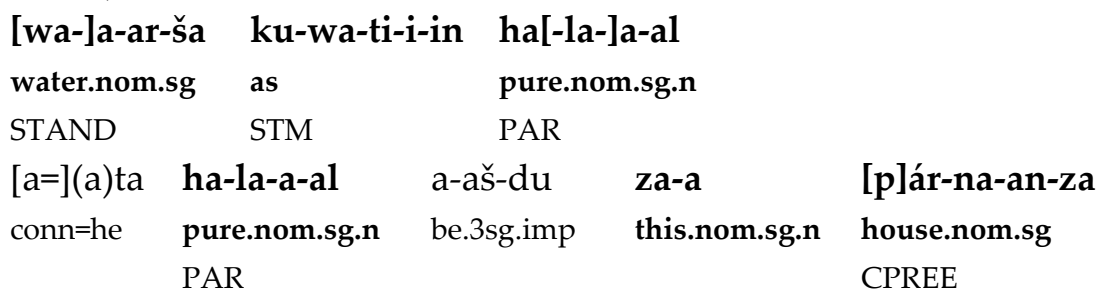

"As water is pure, let this house become pure"

A possible similative, with the verb functioning at the same time as a parameter, as a comparee (in its personal endings), and as a standard (in its root), can also be found in hieroglyphic Luwian (found in ACLT):

(3) BOYBEYPINARI 1-2, IIIB, ACLT

TONITRUS-wa/i-nú-wa/i-tu

treat.like.tarhunt.3sg.imp

PAR+STAND+CPREE

"Let he be treated like Tarhunt (Storm God)"

Unfortunately, no Luwian comparatives could be easily spotted in ACLT by means of automatic analysis, which makes us assume (following previous literature) the syncretic character of comparatives and superlatives in Anatolian languages. In Hittite, thanks to a much bigger corpus, it was possible to spot and analyse contexts with different semantics for comparative and superlative constructions, though superlatives might coincide in form with zero and comparative degrees, or be expressed pragmatically.

For Hittite we can get even more, in terms of quantitative approach. Corpus analysis of myths, prayers, letters and instructions helped us find out that the most frequent type of coding gradation with all types of semantics (similative, comparative, superlative, elative, excessive) was the following: standard marker (STM) and standard (STAND) are not expressed, the pa- 
rameter (PAR) is expressed by an (adjectival) verb or an adjective (takk- 'to be like', mašiwan- 'as much as', nakki- 'important', mekki- 'big', šalli/ya- 'great', šani- 'the same').

(4) $\mathrm{CTH} 458.11 .3(\mathrm{NH}) \mathrm{KBo} 34.34+10$ '-12' (Fragment of incantation)

$\begin{array}{llll}n=a-t & \text { šaniya } & \text { pèta } & z a n u-z z i \\ \text { conn=this-acc.sg.n } & \text { same.dat.sg } & \text { position.dat.sg } & \text { refine-3sg.prs } \\ \text { CPREE } & \text { PM } & & \end{array}$

'This will bring to the same level'

(the context mentions golden cups (GAL KÙ.SIG ${ }_{17}$ ) which should be refined to the same level of value as the cups that the king saw)

The same lexical approach can be seen with equative semantics:

(5) CTH 344 (NH) KUB 33.120+ rev. iii 35’ (Song of Origin)

$\begin{array}{lllll}\text { [...] kuitki } & \text { šalli } & \text { māl } & \text { KUR-e } & \text { maši-wan } \\ \text { frgm indef-nom.sg } & \text { great.nom.sg.n } & \text { valour-nom.sg } & \text { land-nom.sg } & \text { equal-ptcp.nom.sg.n } \\ & \text { PAR CPREE } & & \text { STAND+STM } & \text { PM }\end{array}$

'[...] what valour is as great as the land?'

Similative which uses a postposition as parameter marker (contrary to (4), which was an example of a similative using a verb as parameter marker) is the most frequent case for degrees of gradation in my corpus:

(6) CTH 374 KBo 52.13+ iii 19' (The King's Prayer to the Sun God)

$\begin{array}{lllll}n u & \text { wātar } & \text { māhhanan } & \text { kuwāpi } & \text { ar(a)š-mi } \\ \text { conn } & \text { water.nom.sg } & \text { as } & \text { when } & \text { flow-1sg.prs } \\ & \text { STAND } & \text { STM } & & \text { PAR+CPREE }\end{array}$

'Where (I) flow like water'

Transparent Hittite comparatives are often expressed by verbs - and if we compare Luwian example (3) with their Hittite analogues, it may be assumed that the Luwian context might also be not a similative, but rather a comparative with the meaning 'better' ("treat him like Tarhunt").

(7) CTH 345.I.3 (NH) KBo 26.65+ iv 10 (Song of Ullikummi: the third tablet)

$\begin{array}{lllll}\text { KUR-e } & \text { salli } & \bar{e} s ̌-t a & n=a-t & \text { tepaweš-ta } \\ \text { land-nom.sg } & \text { great-nom.sg.n } & \text { be-3sg.pst } & \text { conn=it-nom.n } & \text { lessen-3sg.pst } \\ \text { STAND } & \text { PARstand } & & \text { CPREE } & \text { PAR+PM }\end{array}$

'The land was great, but it became less'

(8) CTH 345.I.3 (NH) KBo 26.65+ iv 10 (Song of Ullikummi: the third tablet)

$\mathrm{ZI}-a n-z a=m u=k a n \quad$ anda idalawěš- $t a$

soul-nom.sg=me-loc=loc inside become.worse-3sg.pst

CPREE

$\mathrm{PAR}+\mathrm{PM}$

'The soul inside me became worse'

Example (9) is a particularly remarkable case of Hittite comparative semantics. Here the standard of comparison is expressed by the adverb "before": the current state of a person compared to what it was before. It is clear from this example that comparison may be expressed by means that are different from verbs/adjectives, and that the most productive type of delivering this semantics in Anatolian languages was lexical, based upon the meaning of a verb or an adjective, or any other morphological category, for that reason. 
(9) CTH 374 (MH) KBo 52.13+ KUB 36.75 iii 16'-18' (The King's Prayer to the Sun God)

\begin{tabular}{|c|c|c|c|}
\hline $\begin{array}{l}n u=s ̌ s ̌ a n ~ n a m m a \\
\text { conn=loc then }\end{array}$ & $\begin{array}{l}\text { dankuwa-i } \\
\text { dark-loc.sg }\end{array}$ & $\begin{array}{l}\text { takanzip-i } \\
\text { Earth-loc.sg }\end{array}$ & $\begin{array}{l}\text { karuwiliyatt-a } \\
\text { before } \\
\text { STAND }\end{array}$ \\
\hline
\end{tabular}

'I no longer stride on the dark Earth, as before (= I am worse than before)'

\section{Superlatives}

The existence of syncretic comparative and superlative degree in Luwian marked with the PM suffix - zza was proposed by Yakubovich (2013), who supports the position that it is very difficult to spot the difference between comparative and superlative contexts in Luwian. As shown above, contextual analysis allows us to determine the nature of comparison in a sentence, and I would venture to suggest that Luwian contexts with -zza discussed in Yakubovich 2013: 160165 are not comparative, but superlative in their semantics (naturally, this assertion should be discussed in more detail in the future). If it is indeed a grammaticalised form of superlative in Luwian, it might represent the only morphological means to express superlative semantics among the attested Anatolian languages.

Nevertheless, analysis of semantics in available contexts clearly shows that superlatives in $z z a$ in Luwian actually correlate and show the same behaviour with the Hittite superlatives (polar adjectives) meaning 'first among all' (hantezzi-) and 'superior' ('the highest', šarazzi-). The only difference is that Luwian probably went further and for a certain period of its history actually grammaticalised the superlative suffix, whereas Hittite only used polars and ordinals in the function of superlative. Etymologically, suffixes of Luwian and Hittite superlative adjectives are connected with the same Proto-Indo-European suffix *-tio (following Hajnal 2004: 193), typical for polar adjectives (see below on PIE suffixes). In (10) we can see Luwian urazza'the greatest', which often correlates in Hittite prayers with šarazzi- 'the highest, superior'.

(10) CTH 757.A, KUB 9.31 ii 30 (cf. Starke 1985:53³)

$\begin{array}{llll}\text { u-ra-az〈-za-aš` } & \text { dUTU-az } & \text { ta-ti-in-zi } & \text { DINGIR.MEŠ-in-zi } \\ \text { greatest.nom.sg.c } & \text { Sun.God.nom.sg } & \text { fatherly } & \text { god.nom.pl } \\ \text { PAR+PM } & \text { CPREE } & & \end{array}$

"Greatest Sun God, ancestral gods!"

In Hittite superlatives with hantezziyaš 'first' or šarazziyaš 'the highest' are the most frequent ones. Example (11) demonstrates the type in which the marker is explicitly expressed as STAND, GEN.PL, and the parameter is expressed by the polar adjective 'first'; the meaning of the parameter is clearly superlative rather than ordinal.

(11) CTH 344 (NH/NS) KBo 33.120 i 9-10 (Song of the Origin, or Theogony)

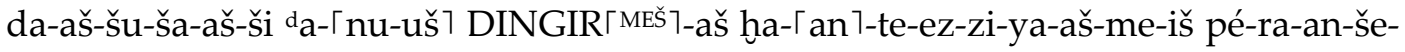
[et] ar- $\lceil\mathrm{ta}\rceil$

\begin{tabular}{|c|c|c|}
\hline$d a \check{s} \check{S} u-\check{s}=a=\check{s} \breve{s} i$ & $\mathrm{~d} a n u-\check{s}$ & DINGIRMEŠ-aš \\
\hline ghty-nom.sg.c=and=he.dat & Anu-nom.sg & god-gen.pl \\
\hline ntezziya & $\begin{array}{c}\text { STAND+STN } \\
\text { peran }=\text { šet }\end{array}$ & $a r-t a$ \\
\hline
\end{tabular}

first-nom.sg.c=their.nom.sg.c before=his.acc.sg.n stand-3sg.pst.med

PAR

'The mighty Anu, the first among the deities, stands before him'

${ }^{3}$ All Luwian examples are cited via Yakubovich 2013 or taken from ACLT. 
Luwian was probably also more advanced than the other Anatolian languages in its grammaticalisation of the adjective hantil(i)- (FRONS-la/i/u) 'first' as a superlative prefix (Yakubovich 2013: 158). Yakubovich points out that in (12) "the semantics of the adverbial modifier /xantili/, which is derived from the Luwian adjective hantil(i)- 'first',... speaks in favour of an implicit comparison with the other gates... reflecting the same phenomenon, namely the superlative construction formed with the help of intensifiers".

(12) KARKAMIŠ A11a §17, Hawkins 2000:1, 95

$\begin{array}{llll}\text { *a-wa/i-tà } & \text { FRONS-la/i/u } & \text { ARGENTUM.DARE-si-ia } & \text { *a-sa-tá } \\ \text { ptcl=ptcl=they.nom.n } & \text { firstly } & \text { costly.nom.pl.n } & \text { be.3sg.pst } \\ \text { CPREE } & \text { PM } & \text { PAR } & \end{array}$

"They were most costly"

The former reminds us of Luwian hantil(i)- discussed above, and of its usage as a superlative prefix. Yakubovich supposes that early Luwian *hantezza, cognate with Hittite hantezzi, was replaced in early Luwian by hantil(i)- in the meaning 'the first' - particularly because of the suffix $-z z a$, which, supposedly, was grammaticalised as a superlative marker for adjectives, whereupon hantil(i)- (FRONS-la/i/u-), in its turn, acquired the superlative meaning as a prefix (Yakubovich 2013: 157-158).

Speaking of marking the standard of comparison, superlative phrases in Hittite either do not express STAND at all, or they express it with GEN.PL in -aš (as described in Hoffner, Melchert 2008: 273 and shown in ex. 11 above). Meanwhile, the parameter of the quality in Hittite might also be marked by a function word, a preposition or by means of information structure (pragmatically).

Ex. (13) uses postpositions (ištarna 'between') as STM and adjectives as parameters.

(13) CTH 376.1 (NH) KUB 24.3 obv. i 30'-32' (Hymn and Prayer to Sun Goddess of Arinna) 「nu 7-ut-ták-kán ŠUM-an lam-na-aš iš-tar-「na na 7-ak-ki-i

DINGIR-LIM-ya-tar-ma-ták-「kán7 DINGIR ${ }^{M E S ̌-a s ̌ ~ i s ̌-t a r-n a ~ n a-a k-k i-i ~}$

nam-ma-za-「kán 7 DINGIRMEš-aš iš-tar-na zi-ik-pát dUTU URUa-ri-in-na na-ak-ki-iš

$\begin{array}{cllll}\text { 1. } n u=t t a=k k a n & \text { ŠUM-an } & \text { lamn-aš } & \text { ištarna } & n a k k \bar{\imath} \\ \text { conn=you.loc.sg=loc } & \text { name-nom.sg } & \text { name-gen.pl } & \text { between } & \text { important.nom.sg.n } \\ & \text { CPREE } & \text { STAND } & \text { STM } & \text { PAR+PM }\end{array}$

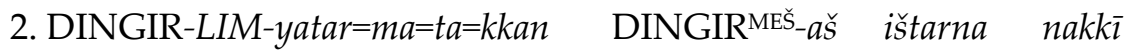

divinity.nom.sg=but=you.loc.sg=loc god-gen.sg between important

CPREE

STAND STM PAR+PM

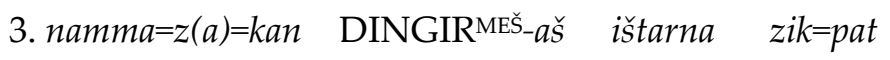

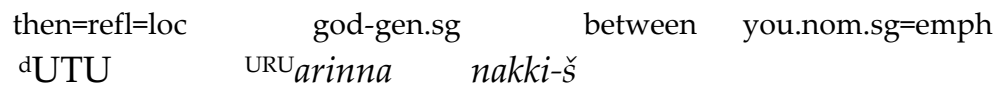

Sun.Goddess city.of.Arinna important-nom.sg.n

CPREE PAR+PM

'1. Your name is (most) important among the names; 2. your divinity is (most) important among the deities; 3 . And you yourself, Sun Goddess of Arinna, are (most) important among the deities'

Ex. (14) is quite remarkable in regard to formal parameters of comparison. STM and STAND here are not expressed at all, and the parameter marker is a particle or is expressed by means of information structure. Actually, the only way superlative semantics can be revealed in this context is contextual analysis. 
(14) CTH 376.1 (NH) KUB 24.3 i 32'-33' (Hymn and Prayer to Sun Goddess of Arinna) 「šal-le1-eš-ša-az zi-ik-pát dUTU URUa-ri-in-na
šalle $\check{s} \check{s}=a=z$
$z i k=p a t$
dUTU
URUarinna
great.nom.sg.c $=$ and $=$ refl
you.nom.sg=emph
Sun.Goddess
city.of.Arinna
PAR
PM
'And great (only) you are, Sun Goddess of Arinna'

In Hittite prayers one regularly finds structures involving zik=pat "and you!", where $z i k$ 'you' doubles the explicitly expressed subject and looks redundant. Its function might be understood as purely grammatical, expressing superlative semantics. The emphatic particle =pat has proven to be consistently marking identificational foci, including those with restrictive meaning 'only $X$ ', and scalar 'the first' / 'the last' (detailed analysis of foci marked with =pat see in Molina 2016, 2018). The form zik=pat, therefore, might have been reserved in Hittite prayers explicitly for those types of semantics that tend to fit in superlatives ('only you', 'the first among others'), underlined by the complex of GEN.PL plus postposition ('among other gods you =pat are the first', vel sim).

In (15) STM and STAND are not expressed; the parameter is the adjective nakkiš 'important', without any parameter markers, so only the background remains as a means to recognise its semantics. What is quite remarkable in this clause is the appearance of $z i k$ 'you' in noncanonical position at the end of the sentence. For Hittite, a strict SOV language, any filled postverbal position should be strongly marked, and we usually surmise the presence of identificational foci, the same as marked by $=p a t$, as discussed above.

(15) CTH 377 (NH) KUB 24.1+KBo $58.10 \S \S 2-5$ (Hymn and Prayer of Mursili II to the Telipinu God)

1. ['te-li-p]í-nu-uš šar-ku-uš n[a-ak-ki-iš] DINGIR-LIM-iš zi-ik (i 3)

dtelipinu-šs šarku-š nakki-š DINGIR-LIM-i-š zik

Telipinu-nom.sg prominent-nom.sg important-nom.sg.c god-nom.sg you.nom.sg

'Telipinu, you are (the most) important god'

2. nu-za-kán ma-「a-an 7 na-ak-ki-「iš $\rceil$ dte-li-pí-nu-uš še-er ne-pí-ši DINGIRMEš-aš iš-tarna (i 8)

\begin{tabular}{|c|c|c|c|}
\hline$=z(a)=k a n$ & $m \bar{a} n$ & $n a k k i-\check{s}$ & dtelipinu-š \\
\hline & if & important-nom.sg.c & Telipinu-nom.sg \\
\hline sky-1 & & $\begin{array}{ll}\text { NGIRMEŚ-aš }^{\text {loštarna }} \\
\text { l-gen.pl } & \text { betweer }\end{array}$ & \\
\hline
\end{tabular}

'Be it up in the sky (the most) important among deities (be it in the mountains, or in battle)'

3. zi-ik-za dte-li-pí-nu-uš na-[ak-ki-i]š DINGIR-LIM-「iš 7 (i 18)

$\begin{array}{llll}z i k=z(a) & \mathrm{d} \text { telipinu-s } & n a k k i-\check{s} & \text { DINGIR-LIM-iš } \\ \text { you.nom.sg=refl } & \text { Telipinu-nom.sg } & \text { important-nom.sg.c } & \text { god-nom.sg } \\ & & \text { PAR }\end{array}$

'You yourself, Telipinu, are (the most) important god'

Elative semantics in Hittite.

To express the idea that " $X$ is very $Y$ ", Hittite uses the word mekki- 'many, much'. It can be seen from (16) and (17) (taken from Hittite letters) that it stands preposed to the modified adjective or verb, the same position in the clause that is taken by Luwian hantili- in (12) above. 
(16) CTH 200 (MH/MS) ABoT 1.6 obv. 20-21 (Letter to the King from Kassu) pé-e-da-an me-ek-ki na-ak-ki

péda-n mekki nakki

place-nom.sg very important.nom.sg

PM PAR

'This place is very important (it is the enemy's granary)'

(17) CTH 181 (NH) KUB 14.3 ii 74-75 (Tawagalawa Letter)

I-NA KUR URUHAT-TI ŠA MUNUS.LUGAL MÁŠ-TU ${ }_{4}$ me-ek-ki šal-li

INA KUR URUHATTI ŠA MUNUS.LUGAL MÁŠ-TU ${ }_{4}$ mekki šalli

in land Hattusa of Queen family very important.nom.sg.n

'In Hatti the Queen's family is very highly regarded'

The only Hittite example with excessive meaning from my corpus involves the verb makkēš'to be/become many, to be/become excessive' (HED M: 122). Structurally, it looks very similar to (7), (8) above with comparative meaning, and to Luwian example (3). It is derived from mekki- 'many, much' by means of the suffix -ēs with the meaning 'become', formally the same process which we saw in comparative semantics (idalaweš-, tepuweš-).

(18) CTH 373 (MH) KUB 30.10 rev. 16-17 (Kantuzzili's Prayer to Sun God)

ki-nu-na-mu-uš-ša-an i-na-an pít-tu-li-ya-aš-ša ma-ak-ke-e-eš-「ta 1

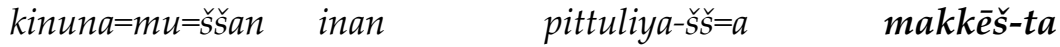

now=me.dat.sg=loc illness.nom.sg anxiety-nom.sg=and become.excessive-3sg.pst

'But now illness and anxiety have become too much for me'

\section{Proto-Indo-European numerals and data from Narrow Indo-European languages}

As mentioned in Luján 2019, fn. 11, there are certain adjectives in the ancient Narrow IndoEuropean languages, basically meaning 'good', 'bad', 'big', and 'small', which form their comparatives and superlatives by means of suppletive forms, - "but the actual suppletions do not seem to go back to PIE". The assertion that the attested forms in ancient NIE languages cannot be based on PIE ones based on our understanding that, though suppletive forms (i.e. forms using different roots) were used for the comparison meaning 'better/best', 'worse/worst' etc., the suffixes of comparative forms were usually the same as the suffixes of the other adjectives involved in comparison, e.g. Gk. $\alpha \mu \varepsilon \iota v \omega v$ 'better' vs. $\alpha \gamma \alpha \theta o s$ 'good'. This can somehow imply that the formation of degrees of comparison as we know them in ancient Indo-European languages, had started and developed already after the split of Indo-Hittite, though the wide distribution of suffixes with clearly common origin (see Luján 2019 for a review) leaves no chance to its being accidental.

It has been suggested in literature (Lundquist \& Yates 2018: 2117 with references) that the comparative suffix *-yos-/-yes-/-is-, shared in common by Indo-Iranian, Latin, Celtic, Greek, Germanic, Baltic, and Slavic, originally had the semantics of an identifier or of an elative marker, and was reinterpreted in phrases with a second element (STAND). Another formative, ${ }^{*}$-tero-, used as a proper comparative in Greek, Indo-Iranian, Italic, and Celtic, can originate from a previously contrastive meaning (Luján 2019: 311). For superlatives, there are three main suffixes: *-isto- (Indo-Iranian, Greek, and Germanic), *-is-mo- (Latin, Celtic), and *-t-mo- (IndoIranian, Latin, Italic). All those suffixes, as Luján rightly points out, "are completely lacking in 
Anatolian, Tocharian, Armenian, and Albanian". While the latter two could have lost the PIE suffixes, the former two suggest that the process of formation of derivational morphology could not have begun earlier than in late PIE, after the split of Proto-Anatolian and ProtoTocharian.

For superlatives in Ancient Greek Fortson (2010) gives the means of expression as positive degree plus GEN.PL (the same as in Hittite (13) above!), arguing that there was probably no synthetic superlative in PIE, and analytic superlative and comparative forms are typologically quite common in the world's languages:

(19) Il. 5.381

$\delta \tilde{\alpha} \alpha \theta \varepsilon \alpha ́ \omega \nu$

'divine of/among goddesses' (= 'most divine goddess')

Now, looking at semantics of comparatives, one might agree with Luján 2019 when he points out that morphology of narrow IE degrees of comparison is close to quantifiers and ordinals. This would be fairly natural: "That dog was the best" and "That dog was the fourth" mostly have very close syntax and shared properties, demonstrated by elliptical tests for numerical and quantificational expressions widely discussed in literature. The semantics of "first" implies its being "in front": some words for 'first' in IE languages derive from the root *pro/*per( $h$ ) 'fore, in front' (Mallory and Adams 2006: 310). Qualities 'first' / 'last' are seen as polars on a scale, which is exactly what we expect from gradation according to the theoretical background explained above. Now we are back to Hittite and Luwian (hantezziyaš, hantil(i)-), discussed above.

In Ancient Greek (Homer) $\pi \alpha v$ - 'all' can be added as an intensifier to the words 'first/last'

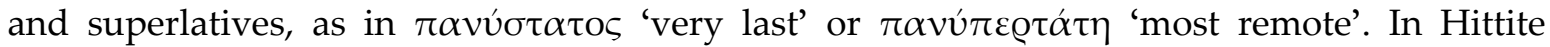
humant- 'all' is regularly used in superlative constructions, as in (20): a positive form of 'great', šalliš, plus GEN.PL, intensified by hūmandaš 'all':

(20) (KBo 3.7 iv 15-17 (Illuyanka myth, OH/NS)

\begin{tabular}{|c|c|c|c|c|}
\hline$n u$ & DINGIR.MEŠ-naš & ḩūmand-aš & $\breve{S} A$ & URU Kaštama \\
\hline $\begin{array}{l}\text { conn } \\
\mathrm{d} Z a s ̌ s\end{array}$ & $\begin{array}{l}\text { god-gen.pl } \\
\text { apunā-šs }\end{array}$ & all-gen.pl & & city.of.Kastama \\
\hline šb & na-nom.sg.c import & an & & \\
\hline
\end{tabular}

"Bearing in mind the close semantic relationship of the superlatives and the words for 'first' and 'last' and their shared properties, we now have a closer look at the relationship between the morphology of ordinals and superlatives in the old Indo-European languages. A nice, significant pattern seems to emerge: *to and * $m o$ appear in the outer part of the superlative suffixes of a language only if they are used in the words for 'first' and 'last'" (Luján 2019: 325). This, in its turn, leads to the idea that suffixes for superlatives in Narrow Indo-European languages developed with the aid of the words 'first/last', which is only natural when one talks of gradation.

But this also explains contexts with pragmatically marked parameters of gradation: some of the identificational foci, e.g. those marked with Hittite particle =pat and word order in Hittite, have the same semantics ('first'/'last' on the scale). See also Matushansky 2008: 28, fn. 6, for further evidence that ordinals, sequentials (next, last, former, and latter) and adjectives that can license a null noun (same and other) frequently have superlative or comparative morphology and syntax. 
The same scenario as described for comparative and superlative suffixes in Narrow IndoEuropean languages is suggested in Yakubovich 2013 for the Proto-Anatolian suffix *-tio- $\rightarrow$ $-z z a$ in Luwian and -zzi(ya)- in Hittite, with the difference that in Luwian one could spot contexts where this suffix has already grammaticalised as a superlative one, and in Hittite it still functions as part of polar adjectives. Pragmatic uses for the needs of superlative and comparative semantics only additionally prove the fact that Proto-Anatolian degree morphology, as well as in late Proto-Indo-European, is derived from expressions denoting the place of an entity on a scale.

\section{Gradation degrees in Indo-European family: not before the Indo-Hittite split}

Summing up, we can see that both from the typological standpoint and based on the comparison with Indo-European languages, the formation of degree morphology could not start earlier than in late Indo-European languages: it left Anatolian languages, such as Hittite, completely uninvolved, and was accomplished by other means in Luwian. Meanwhile, it is clear that the processes in ancient Indo-European languages had a similar character - derivation of degree constructions are universally based on polar adjectives, particularly on the semantics and morphology of 'first/last', but also on pragmatic ways to express the semantics of polarity, including identificational foci. This suggests another direction to look at if we are in search of origins for gradation morphology.

\section{Abbreviations of sources}

ABoT - Tablets from Archaeological Museum of Ankara (Ankara Arkeoloji Muezesinde Bulunan Bogazkoy Tabletleri); ACHC - Annotated Corpus of Hittite Clauses, http://hittitecorpus.ru; ACLT - Annotated Corpus of Luwian Texts, http://web-corpora.net/LuwianCorpus; CHD - Goedegebuure et al. 1980-2019; CMHD - Ünal 2007; CTH - Catalogue of Hittite Texts (Catalogue des textes hittites); EDHIL - Kloekhorst 2008; HED - Puhvel 1984-2017; HHW = Tischler 2001; HW - Friedrich \& Kammenhuber 1975-2017; IBoT - Tablets from Istanbul Archaeology Museums (Istanbul Arkeoloji Muezelerinde Bulunan Bogazkoy Tabletleri); KBo - Cuneiform texts from Bogazkoy (Keilschrifttexte aus Boğazköy); KUB - Cuneiform documents from Bogazkoy (Keilschrifturkunden aus Boğazköy).

\section{References}

Dixon, Robert M. W. 2012. Comparative constructions. In: Dixon, R. M. W. Basic Linguistic Theory. Volume 3. Further Grammatical Topics: 343-375. Oxford University Press.

Eichner, Heiner. 1992. Anatolian. In: J. Gvozdanovic (ed.). Indo-European Numerals. Trends in Linguistics, Studies and Monographs 57: 29-96. Berlin / New York: De Gruyter.

Fortson, Benjamin W. 2010. Indo-European Language and Culture. 2nd. ed. Chichester/Malden: Wiley-Blackwell.

Friedrich, Johannes, Annelies Kammenhuber. 1975-2017. Hethitisches Wörterbuch. Heidelberg: Universitätsverlag Carl Winter.

Goedegebuure, Petra M. et al. (eds.). 1980-2019. The Hititte Dictionary of the Oriental Institute of the University of Chicago. 1980-. Chicago: Oriental Institute.

Gorshenin, Maksym. 2012. The crosslinguistics of the superlative. In: Cornelia Stroh (ed.). Neues aus der Bremer Linguistikwerkstatt. Aktuelle Themen und Projekte: 55-160. Bremen: Brockmeyer.

Hajnal, Ivo. 1995. Die lykischen a-Stämme. In: Jens E. Rasmussen (ed.). In honorem Holger Pedersen. Kolloquium der Indogermanischen Gesellschaft vom 26. bis 28. März in Kopenhagen: 135-171. Wiesbaden: Reichert. 
Hahnemann, Suzan. 1999. Vergleiche im Vergleich. Zur Syntax und Semantik ausgewählter Vergleichsstrukturen mit 'als' und 'wie' im Deutschen. Tübingen: Niemeyer.

Haspelmath, Martin. 2017. Equative constructions in world-wide perspective. In: Yvonne Treis, Martine Vanhove (eds.). Similative and Equative Constructions. A cross-linguistic perspective: 9-32. Amsterdam/Philadelphia: John Benjamins.

Haspelmath, Martin, Oda Buchholz. 1998. Equative and similative constructions in the languages of Europe. In: Johan van der Auwera (ed.). Adverbial constructions in the languages of Europe: 277-334. Berlin: Mouton de Gruyter.

Hawkins, John David. 2000. Corpus of Hieroglyphic Luwian Inscriptions. Vol. 1: A Reference Grammar. Winona Lake: Eisenbrauns.

Hoffner, Harry. 1993. Hittite iwar and related modes of expressing comparison. Istanbuler Mitteilungen 43: 39-51.

Hoffner, Harry. 2009. Letters from the Hittite Kingdom. Atlanta: Society of Biblical Literature.

Hoffner, Harry, H. Craig Melchert. 2008. A Grammar of the Hittite Language. Winona Lake: Eisenbrauns.

Kloekhorst, Alwin. 2008. Etymological Dictionary of the Hittite Inherited Lexicon. Leiden/Boston: Brill.

Lundquist, Jesse, Anthony D. Yates. 2018. The Morphology of Proto-Indo-European. In: Jared S. Klein, Brian D. Joseph (eds.). The Handbook of Comparative and Historical Indo-European Linguistics: 2079-2195. Berlin / New York: de Gruyter.

Luján, Eugenio R. 2019. On Indo-European superlative suffixes. Indogermanische Forschungen 124(1): 305-342. doi:10.1515/if-2019-0012.

Mallory, James P., Douglas Q. Adams. 2006. The Oxford Introduction to Proto-Indo-European and the Proto-IndoEuropean World. Oxford University Press.

Matushansky, Ora. 2008. On the attributive nature of superlatives. Syntax 11(1): 26-90.

Miller, Jared L. 2013. Royal Hittite Instructions and Related Administrative Texts. Atlanta: Society of Biblical Literature.

Molina, Maria. 2016. Emfaticheskaja enklitika =pat v xettskom jazyke: analiz funkcij i semantika markirujemyx fokusov ('The emphatic enclitic =pat in Hittite: analysis of function and semantics of the marked foci'). In: N. N. Kazanskij (ed.). Indoevropejskoje jazykoznanije i klassicheskaja filologija. XX. Materialy chtenij, posv'ashchennyx pam'ati professora I. M. Tronskogo: 739-754. Sankt-Petersburg: Nauka.

Molina, Maria. 2019. Word order in Hittite. PhD Thesis. Moscow: Institute of Linguistics of the Russian Academy of Sciences.

Puhvel, Jaan. 1984-2017. Hittite Etymological Dictionary. Berlin / New York / Amsterdam: Mouton de Gruyter.

Rieken, Elisabeth et al. 2017-. Gebete der Hethiter. Available online at: http://www.hethiter.net/txhet_gebet.

Rieken, Elisabeth et al. 2009-. Mythen der Hethiter. Available online at: http://www.hethiter.net/ txhet_myth.

Small, George W. 1924. The comparison of inequality. The semantics and syntax of the comparative particle in English. Baltimore: John Hopkins University.

Starke, Frank. 1985. Die keilschrift-luwischen Texte in Umschrift. Wiesbaden: Harrassowitz.

Tischler, Johann. 2001. Hethitisches Handwörterbuch. Innsbruck: Institut für Sprachen und Literaturen der Universität Innsbruck.

Ünal, Ahmet. 2007. Concise Multilingual Hittite Dictionary. Hamburg: Verlag Dr. Kovac.

Yakubovich, Ilya. 2010. Sociolinguistics of the Luvian language. Leiden: Brill.

Yakubovich, Ilya. 2013. The degree of comparison in Luwian. Indogermanische Forschungen 118: 155-168. doi:10.1515/indo.2013.118.2013.155.

Yakubovich, Ilya. 2019. Luvijskij jazyk v prostranstve i vremeni ('The Luwian language in space and time'). Moskva: Jazyki slav'anskoj kul'tury.

Yakubovich, Ilya, Maksim Kudrinski. 2016. Sumerograms and Akkadograms in Hittite: Ideograms, Logograms, Allograms, or Heterograms? Altorientalische Forschungen 43(1-2): 53-66. doi: 10.1515/aofo-2016-0018.

М. А. Молина. Степени сравнения в хетто-лувийских языках.

В работе анализируются формы, зафиксированные для выражения степеней сравнения в хеттском языке, включая конструкции со значением равенства (экватива), сходства (симилятива), сравнения (компаратива), превосходства (суперлатива), значительной степени (элатива) и чрезмерного количества (эксессива). Обработанный материал 
включает хеттские мифы, молитвы, письма и инструкции, в сранении с данными текстов на лувийском языке. Результаты анализа могут дать нам ключи к пониманию процессов формирования грамматической категории степеней сравнения в древних индоевропейских языках после распада праиндоевропейского единства и к вероятной реконструкции степеней сравнения для праантолийского и праиндоевропейского. Корпусный подход к хеттскому и лувийскому материалу и контекстный анализ позволяет, кроме прочего, выделить неочевидные конструкции, в которых значение сравнения задано прагматически, а не морфологически, и тем самым расширить наше представление о способах выражения семантики сравнения в анатолийских языках. Данная работа, таким образом, направлена на понимание ранних этапов грамматикализации форм сравнения в индоевропейских языках на основе анатолийского материала.

Ключевые слова: хеттский язык; синтаксис; степени сравнения; историческая семантика; корпусный подход. 